Л.П. Грес/д.т.н./,

О.В. Гупало /к.т.н./,

О.О. Срьомін /д.т.н./,

Є.О. Каракаш /к.т.н./,

Е.К. Д'якова
Національна металургійна академія

України, м. Дніпро, Україна

\title{
ДОСЛІДЖЕННЯ ЕФЕКТИВНОСТІ ВИКОРИСТАННЯ ТЕХНОЛОГІЧНОГО КИСНЮ ПРИ ОПАЛЕННІ ТЕПЛОТЕХНІЧНИХ МЕТАЛУРГІЙНИХ АГРЕГАТІВ
}

\author{
L.P. Gres /Dr. Sci. (Tech.)/, \\ O.V. Gupalo /Cand. Sci. (Tech.)/, \\ O.O. Yeromin /Dr. Sci. (Tech.)/, \\ Ye.O. Karakash /Cand. Sci. (Tech.)/, \\ E.K. Diakova
}

\section{RESEARCH ON THE EFFICIENCY OF THE USE OF PROCESS OXYGEN TO ENRICH THE COMBUSTION AIR IN METALLURGICAL HEATING EQUIPMENT}

\begin{abstract}
Мета - розробка методики визначення ефективності використання технологічного кисню для збагачення повітря горіння при опаленні теплотехнічних агрегатів в металургії.

Методика. Під час виконання дослідження використано: математичну модель повітронагрівача, яка дозволяє при заданих його конструктивних параметрах та витраті дуття визначати витрати палива, повітря горіння і димових газів, зміну температури димових газів $i$ дуття по висоті насадки; методику розрахунку горіння палива та визначення калориметричної температури його горіння; методику розрахунку коефіцієнта використання теплоти палива.

Результати. Дослідження теплової роботи блоку повітронагрівачів доменної печі дозволило визначити, що використання технологічного кисню для збагачення повітря горіння забезпечує роботу повітронагрівачів на доменному газі і задану температуру дуття при вмісті кисню у повітрі горіння $26 \%$, але потребує збільшення витрати доменного газу на $32 \%$. При цьому питомі витрати на опалення блоку повітронагрівачів збільшуються на 20,9\%, що робить впровадження иього заходу економічно недочільним. Дослідження зміни показників енергоефективності методичної печі та парового котла при їх опаленні природним газом та використанні для спалювання палива атмосферного або збагаченого киснем повітря дозволило встановити, щьо ефективність використання кисню в методичній печі є значно вищою, ніж в котлах. При підвищенні вмісту кисню в повітрі горіння до $31 \%$ економія палива в методичній печі складає 11,6\%, а питома витрата технологічного кисню - 6,28 $\mathrm{m}^{3} / \mathrm{M}^{3}$ заошадженого природного газу, в той час як в котлі иі показники відповідно складають $1,7 \%$ ma $48,67 \mathrm{~m}^{3} / \mathrm{m}^{3}$.

Наукова новизна. 3 використанням розрахункових методів та математичного моделювання теплової роботи доменних повітронагрівачів обтрунтовано, що використання технологічного кисню для збагачення повітря горіння забезпечує отримання заданої температури дуття та економію природного газу, але потребує суттєвого збільшення витрати доменного газу. Встановлено аналітичну залежність, що обтрунтовує максимальну вартість технологічного кисню для його беззбиткового використання в доменних повітронагрівачах. Для нагрівальних печей та парових котлів, щьо опалюються природним газом та використовують для спалювання палива атмосферне повітря, збагачене технологічним киснем, встановлено аналітичні залежності, які дозволяють визначати: витрату технологічного кисню для економії $1 \mathrm{м}^{3}$ палива; максимальну
\end{abstract}

(C) Грес Л.П., Гупало О.В., Єрьомін О.О., Каракаш Є.О., Д’якова Е.К., 2019 г. 
вартість технологічного кисню, при якій його застосування не призводить до зростання сумарних витрат на паливо та технологічний кисень.

Практична значущість. Розроблені методики визначення ефективності використання технологічного кисню для збагачення повітря горіння при спалюванні палива можуть застосовуватися в системах енергетичного менеджменту металургійного комбінату для управління тепловим балансом підприсмства і вибору теплотехнічних агрегатів, в яких використання тимчасових надлишків технологічного кисню дозволяє забезпечити найбільшу економію палива та є економічно доцільним.

Ключові слова: повітронагрівач, піч, котел, паливо, природний газ, доменний газ, технологічний кисень.

\section{DOI: 10.34185/0543-5749.2019-3-4-14-24}

Вступ. За даними ОП «Укрметалургпром» споживання природного газу металургійними підприємствами України в 2018 р. досягло 1,84 млрд. ${ }^{3}$ [1]. Зниження витрат природного газу при виробництві металургійної продукції може бути досягнуто впровадженням новітніх технологій виробництва, підвищенням енергоефективності роботи металургійних агрегатів, оптимізацією паливно-енергетичного балансу металургійних підприємств, повним використанням власних вторинних енергетичних ресурсів.

Вагомими споживачами природного газу на металургійних комбінатах є теплотехнічні агрегати: повітронагрівачі доменних печей; нагрівальні та термічні печі прокатних цехів; котли теплоелектроцентралі (ТЕЦ). Одним 3 відомих шляхів підвищення їх енергоефективності є використання технологічного кисню для спалювання палива. Технологічний кисень може використовуватись для збагачення повітря, що подається на спалювання палива, або в якості окислювача, замість атмосферного повітря.

На металургійних підприємствах країн Західної Європи, США і Південної Кореї до 2009 р. 120 печей було спроектовано і введено в експлуатацію або переведено на газокисневе спалювання палива [2]. Роботи в цьому напрямку продовжуються і по теперішній час. Зарубіжними компаніями розроблено низку пальникових пристроїв, які реалізують технологію газокисневого спалювання палива (як правило, природного газу) $[3,4]$. Застосування цієї технології, в порівнянні зі спалюванням палива з атмосферним повітрям, забезпечує $3-4$ кратне зменшення об'єму продуктів згоряння, збільшення температури горіння палива і дворазове підвищення випромінювальної здатності факела [2]. Це призводить до підвищення продуктивності агрегатів на 25 - 50\%, економії палива на $30-60 \%$ (в залежності від конкретних умов виробництва), підвищення якості теплової обробки матеріалів та спрощення конструкції теплового агрегату [3,
5 - 7]. У певних умовах можливе зниження угару металу і кількості шкідливих викидів в навколишнє середовище.

При всіх перевагах газокисневого спалювання палива його застосування на українських металургійних комбінатах має низку проблем:

1) низька інвестиційна спроможність підприємств в розвиток та технічне переоснащення виробництва;

2) циклічні зміни цін на металургійну продукцію, а отже і прибутків підприємств;

3) значне коливання цін на енергоресурси;

4) залежність роботи реконструйованого агрегату від наявності технологічного кисню на підприємстві;

5) неможливість відмовитися від газокисневого спалювання палива без повторної реконструкції агрегату, заміни пальників і модернізації допоміжного обладнання.

Тому в Україні та пострадянських країнах технологічний кисень при спалюванні палива, як окислювач, практично не застосовується [8 - 10].

Однією з особливостей вітчизняних металургійних комбінатів $\epsilon$ неритмічність роботи основних споживачів технологічного кисню, яка призводить до появи його тимчасових надлишків. Ці надлишки досягають 5 - 10 \% від загального обсягу виробництва кисню i, при відсутності накопичувачів, зазвичай скидаються в атмосферу. В той же час надлишковий технологічний кисень може бути використаний в теплотехнічних металургійних агрегатах для збагачення повітря, що подається на горіння палива. Збагачення повітря технологічним киснем при спалюванні палива не потребує значних інвестицій на заміну обладнання та реконструкцію агрегату i не призводить до виникнення загрози зупинки виробництва у разі затримки постачання кисню або до значного збільшення собівартості продукції у разі стрімкого зростання його ціни.

Підвищення частки кисню у повітрі горіння $\epsilon$ настільки ж потужним засобом підвищення 
ефективності використання теплоти палива, як i збільшення температури підігріву атмосферного повітря [2]. Збільшення вмісту кисню в повітрі зменшує баласт у вигляді азоту, а, отже, і питомий вихід димових газів, в результаті чого знижуються теплові втрати 3 димовими газами, що відходять. Також збільшується коефіцієнт використання теплоти палива та калориметрична температура горіння.

Зміна попиту на металургійну продукцію визначає зміну обсягів виробництва $i$, найчастіше, призводить до виникнення на підприємстві тимчасових (а під час і довготривалих) надлишків технологічного кисню, які можуть бути скинуті в атмосферу і втрачені, або використані для збагачення повітря горіння в теплотехнічних агрегатах. У таких випадках особливу актуальність набуває вирішення проблеми раціонального розподілу технологічного кисню між потенційними споживачами, які характеризуються різними режимами роботи, організацією процесів спалювання палива, показниками енергоефективності. Метою даної роботи $є$ розробка методики визначення ефективності застосування технологічного кисню для збагачення повітря горіння при опаленні теплотехнічних агрегатів металургійного комбінату (повітронагрівачів доменних печей, нагрівальних печей прокатного виробництва і котлів ТЕЦ); обгрунтування максимальної ціни технологічного кисню, що забезпечує беззбитковість його використання в теплотехнічних агрегатах, що розглядаються.

Методика дослідження. Для визначення ефективності використання технологічного кисню при нагріванні доменного дуття використано математичну модель повітронагрівача 3 вбудованою камерою горіння [11], яка дозволяє виконувати розрахунок його теплової роботи та, при заданих витраті дуття і конструктивних параметрах повітронагрівача, визначати витрату палива, повітря горіння і димових газів, зміну температури димових газів і насадки по ії висоті в період нагрівання, а також зміну температури дуття по висоті насадки в період дуття.

В якості вихідних даних для розрахунку задаються: склад палива, його вологість та умови спалювання; температури холодного і гарячого дуття; витрата дуття, що нагрівається; швидкість руху повітря в насадці; тривалість періодів нагрівання і дуття; характеристики насадки (висота, діаметр каналів, відносна поверхня нагріву, площа «живого» перерізу насадки, загальна площа поверхні нагріву, кількість та матеріал ярусів насадки).
Моделювання теплової роботи повітронагрівача передбачає виконання розрахунку горіння палива з визначенням теоретичної і дійсної витрат повітря, питомого виходу диму, складу продуктів згоряння і калориметричної температури горіння палива. Температура під куполом повітронагрівача визначається як:

$$
t_{\text {dome }}=t_{\text {кал }} \cdot \eta_{\text {pyr }},{ }^{\circ} \mathrm{C},
$$

де $t_{c a l}$ - калориметрична температура горіння палива, ${ }^{\circ} \mathrm{C} ; \eta_{p y r}-$ пірометричний коефіцієнт, який враховує умови спалювання палива і теплові втрати повітронагрівача в навколишнє середовище. За даними [11], для повітронагрівачів з винесеною камерою горіння $\eta_{p y r}=0,93$.

Подальші розрахунки виконуються для кожного ярусу насадки та передбачають визначення кількості теплоти, що засвоюється насадкою, коефіцієнта використання теплоти палива, втрат теплоти в камері горіння і загальної теплової потужності повітронагрівача, витрат палива, повітря горіння і димових газів. Далі розраховуються параметри теплообміну (коефіцієнти тепловіддачі випромінюванням і конвекцією від диму до насадки) і ентальпія димових газів, за величиною якої визначається температура диму на виході 3 насадки повітронагрівача. Обчислюються коефіцієнти теплопередачі насадки i температурне поле по висоті ярусу в періоди нагрівання і дуття. За відомими температурами теплоносіїв на вході і виході з ярусу насадки розраховується середня різниця температур між димовими газами і дуттям кожного ярусу, визначаються площі поверхні нагріву кожного ярусу, сума яких є розрахунковою площею поверхні насадки повітронагрівача. Далі розрахункова площа порівнюється із заданою у вихідних даних. Якщо відносна похибка розрахунку площі поверхні нагріву перевищує $1 \%$, то перезадаються прийнятими у вихідних даних параметрами (швидкістю руху дуття в насадці, температурами нагріву дуття i диму на виході 3 насадки, витратою палива). Ознакою завершення розрахунку є досягнення величини відносної похибки менше $1 \%$.

В якості базового варіанту розглядається робота блоку повітронагрівачів, який обслуговує доменну піч. Прийнято, що повітронагрівачі опалюються змішаним газом (природнодоменною сумішшю). Для спалювання палива використовується атмосферне повітря. Склад палива і умови його спалювання забезпечують задану калориметричну температуру горіння палива $t_{c a l}^{*}$ i, згідно рівнянню (1), задану темпе- 
ратуру під куполом повітронагрівачів $-t_{d o m e}^{*}$.

При переведенні повітронагрівача на опалення доменним газом i спалюванні палива зі збагаченим киснем повітрям, для забезпечення вихідних параметрів теплообміну в насадці, а отже і заданої температури підігріву дуття, необхідно підтримувати таку ж саму витрату димових газів, як при опаленні повітронагрівача змішаним газом:

$$
V_{f g}=V_{f g}^{O_{2}}
$$

де $V_{f g}=B_{1} \cdot v_{f g}$ - витрата диму, що проходить крізь насадку повітронагрівача, при опаленні змішаним газом та використанні атмосферного повітря для спалювання палива, $\mathrm{M}^{3} /$ год; $V_{f g}^{O_{2}}=B_{2} \cdot v_{f g}^{O_{2}}-$ витрата диму, що проходить крізь насадку, при опаленні доменним газом та використанні збагаченого киснем повітря, м/год; $B_{1}$ и $B_{2}-$ витрати змішаного та доменного газів відповідно, м³/год; $v_{f g}-$ питома витрата диму при спалюванні змішаного газу з атмосферним повітрям, $\mathrm{M}^{3} / \mathrm{M}^{3} ; \mathrm{v}_{f g}^{O_{2}}-$ питома витрата диму при спалюванні доменного газу зі збагаченим киснем повітрям, $\mathrm{M}^{3} / \mathrm{M}^{3}$.

Таким чином, годинна витрата доменного газу на опалення одного повітронагрівача може бути визначена 3 умови (2):

$$
B_{2}=B_{1} \cdot \frac{\cup_{f g}}{\cup_{f g}^{O_{2}}}, \mathrm{~m}^{3} / \text { год. }
$$

Для визначення частки кисню в повітрі горіння $k_{O_{2}}$, що подається на спалювання доменного газу, та відповідної ій питомої витрати диму $v_{f g}^{O_{2}}$, виконуються розрахунки горіння палива та калориметричної температури при спалюванні доменного газу і різній концентрації кисню в повітрі горіння. Визначаються: витрати кисню, атмосферного та збагаченого повітря, склад продуктів згоряння палива, питомий вихід диму, калориметрична температура і температура під куполом повітронагрівача. За результатами розрахунків методом лінійної інтерполяції визначається частка кисню в повітрі горіння, при якій забезпечуються такі ж самі калориметрична температура $\left(t_{c a l}^{*}\right)$ і температура під куполом повітронагрівача $\left(t_{c a l}^{*}\right)$, як при опаленні змішаним газом.
Витрата технологічного кисню на один повітронагрівач визначається як:

$$
B_{O_{2}}=B_{2} \cdot V_{O_{2}}, \mathrm{M}^{3} / \text { год, }
$$

де $V_{O_{2}}$ - витрата кисню при спалюванні $1 \mathrm{~m}^{3}$ доменного газу $\left(\mathrm{m}^{3} / \mathrm{M}^{3}\right)$, яка згідно роботи [12], розраховується за формулою:

$$
V_{O_{2}}=n \cdot \frac{100 \cdot k_{O_{2}}-21}{79 \cdot \frac{O_{2 . t e c h}}{100}} \cdot \frac{0,21}{k_{O_{2}}} \cdot L_{0}^{\text {air }}, \mathrm{m}^{3} / \mathrm{M}^{3} \text {, }
$$

де $\mathrm{n}$ - коефіцієнт витрати повітря; $k_{O_{2}}$ - частка кисню в повітрі горіння; $O_{2 . t e c h}-$ об'ємний відсоток кисню в технологічному кисні, що подається на збагачення повітря; $L_{0}^{\text {air }}$ - теоретична витрата повітря при спалюванні палива (доменного газу) 3 атмосферним повітрям, $\mathrm{m}^{3} / \mathrm{m}^{3}$.

Годинні та питомі витрати на паливо та технологічний кисень для блоку повітронагрівачів розраховуються за формулами:

$$
\begin{aligned}
& C_{\Sigma}=(N-1) \cdot\left(B_{b f g} \cdot C_{b f g}+\right. \\
& \left.+B_{n g} \cdot C_{n g}+B_{O_{2}} \cdot C_{O_{2}}\right), \text { грн/год, } \\
& C_{\Sigma}^{\prime}=\frac{C_{\Sigma}}{V_{b}}, \text { грн } / \mathrm{M}_{\text {дуття }}^{3},
\end{aligned}
$$

де $N$ - кількість повітронагрівачів в блоці, шт; $B_{b f g}, B_{n g}, B_{O_{2}}$ - годинні витрати доменного та природного газів і технологічного кисню на один повітронагрівач відповідно, м³/год; $C_{b f g}$, $C_{n g}, C_{O_{2}}-$ ціни доменного та природного газів i технологічного кисню відповідно, грн $/ \mathrm{m}^{3} ; V_{b}-$ витрата дуття, $\mathrm{m}^{3} /$ год.

Економічна ефективність використання кисню визначається зміною витрат на паливо і технологічний кисень:

$$
\Delta C_{\Sigma}=C_{\Sigma_{1}}-C_{\Sigma_{2}}, \text { грн/год, }
$$

або

$$
\Delta C_{\Sigma}^{\prime}=C_{\Sigma_{1}}^{\prime}-C_{\Sigma_{2}}^{\prime}, \Gamma \mathrm{pH} / \mathrm{M}_{\text {дуття }}^{3},
$$

де $C_{\Sigma_{1}}, C_{\Sigma_{1}}^{\prime}-$ годинні та питомі витрати на паливо при опаленні змішаним газом відповідно; $C_{\Sigma_{2}}, C_{\Sigma_{2}}^{\prime}-$ відповідно годинні та питомі витрати на паливо при опаленні повітронагрівачів доменним газом при збагаченні повітря горіння киснем, грн/год.

Максимальна ціна технологічного кисню, що забезпечує беззбитковість його використання, визначається із умови $\Delta C_{\Sigma}=0$, яка з урахуванням (6): 


$$
\begin{aligned}
& C_{O_{2}}^{\max }=\frac{1}{B_{O_{2}}} \cdot\left(B_{n g} \cdot C_{n g}-\right. \\
& \left.-\left(B_{b f g 2}-B_{b f g 1}\right) \cdot C_{b f g}\right), г р н / \mathrm{M}^{3},
\end{aligned}
$$

де $B_{b f g 1}, B_{b f g 2}$ - годинні витрати доменного газу при спалюванні палива з атмосферним та збагаченим киснем повітрям відповідно, м $^{3} /$ год.

Методика визначення ефективності використання технологічного кисню при спалюванні природного газу в нагрівальних печах та парових котлах ТЕЦ основана на виконанні розрахунків горіння палива [13] та аналізі зміни коефіцієнтів використання теплоти палива (КВТ) в теплотехнічних агрегатах в залежності від технологічних умов його спалювання.

Економічний ефект при збагаченні повітря горіння киснем може бути визначений $з$ наступного співвідношення:

$$
\Delta C_{\Sigma}^{\prime}=\Delta B_{n g}^{\prime} \cdot C_{n g}-B_{O_{2}}^{\prime} \cdot C_{O_{2}}, \Gamma \mathrm{pH} / \mathrm{T},
$$

де $\Delta B_{n g}^{\prime}$ - питома економія природного газу, $\mathrm{M}^{3} / \mathrm{T} ; B_{O_{2}}^{\prime}-$ питома витрата технологічного кисню, $\mathrm{M}^{3} / \mathrm{T}$.

Згідно даним роботи [14], економія палива розраховується як:

$$
\Delta B_{n g}^{\prime}=B_{n g 1}^{\prime} \cdot\left(1-\frac{\eta_{1}}{\eta_{2}}\right), \mathrm{M}^{3} / \mathrm{T},
$$

або:

$$
E_{n g}=\frac{\Delta B_{n g}^{\prime}}{B_{n g 1}^{\prime}} \cdot 100=\left(1-\frac{\eta_{1}}{\eta_{2}}\right) \cdot 100, \%,
$$

де $B_{n g 1}^{\prime}-$ питома витрата природного газу при роботі на атмосферному повітрі, м³/т; $\eta_{1}$ - коефіцієнт використання теплоти палива при роботі на атмосферному повітрі; $\eta_{2}-$ коефіцієнт використання теплоти палива при роботі на повітрі, збагаченому технологічним киснем.

Питома витрата технологічного кисню, 3 урахуванням (5) і (12), складе:

$$
\begin{aligned}
& B_{O_{2}}^{\prime}=B_{n g 1}^{\prime} \cdot \frac{\eta_{1}}{\eta_{2}} \cdot V_{O_{2}}=B_{n g 1}^{\prime} \cdot \frac{\eta_{1}}{\eta_{2}} \cdot n \times \\
& \times \frac{100 \cdot k_{O_{2}}-21}{79 \cdot \frac{O_{2 . t e c h}}{100}} \cdot \frac{0,21}{k_{O_{2}}} \cdot L_{0}^{\text {air }}, \mathrm{M}^{3} / \mathrm{T},
\end{aligned}
$$

де $L_{0}^{\text {air }}$ - теоретична витрата повітря при спалюванні палива (природного газу) 3 атмосферним повітрям, $\mathrm{m}^{3} / \mathrm{M}^{3}$.

Максимальна вартість технологічного кисню, при якій його застосування $€$ економічно доцільним, визначається 3 рівняння (11) при $\Delta C_{\Sigma}^{\prime}=0$ :

$$
C_{O_{2} \max } \leq \frac{\Delta B_{n g}^{\prime}}{B_{O_{2}}^{\prime}} \cdot C_{n g}, \Gamma \mathrm{pH} / \mathrm{M}^{3} .
$$

Із рівнянь (14) та (12) можуть бути визначені очікувані витрати технологічного кисню для економії $1 \mathrm{~m}^{3}$ газу $\left(B_{O_{2}}^{\prime} / \Delta B_{n g}^{\prime}, \mathrm{m}^{3} / \mathrm{M}^{3}\right)$ :

$$
\begin{aligned}
& \frac{B_{O_{2}}^{\prime}}{\Delta B_{n g}^{\prime}}=\frac{\eta_{1}}{\eta_{2}-\eta_{1}} \cdot V_{O_{2}}= \\
& =\frac{\eta_{1}}{\eta_{2}-\eta_{1}} \cdot n \cdot \frac{100 \cdot k_{O_{2}}-21}{79 \cdot \frac{O_{2 . t e c h}}{100}} \cdot \frac{0,21}{k_{O_{2}}} \cdot L_{0}^{\text {air }}
\end{aligned}
$$

Вартість енергоносіїв істотно впливає на економічну ефективність використання технологічного кисню в теплотехнічних агрегатах. Якщо ціна кисню не враховується ( $\left.C_{O_{2}}=0\right)$, економічний ефект від його застосування буде максимальним і дорівнювати вартості заощадженого палива. У разі, якщо технологічний кисень відпускається споживачам по його собівартості, або вищий ціні, економічний ефект може виявитися негативним.

Дослідження ефективності використання

\begin{tabular}{|c|c|}
\hline $\begin{array}{l}\text { Відносний «живий» переріз } \\
\text { насадки, м²/м² }\end{array}$ & 0,36 \\
\hline $\begin{array}{l}\text { Питома поверхня нагріву } \\
\text { насадки, } \mathrm{m}^{2} / \mathrm{M}^{3}\end{array}$ & 48,0 \\
\hline $\begin{array}{l}\text { Об'єм вогнетривів в } 1 \mathrm{~m}^{3} \\
\text { насадки, } \mathrm{m}^{3} / \mathrm{M}^{3}\end{array}$ & 0,64 \\
\hline Загальна висота насадки, м & 37,10 \\
\hline $\begin{array}{l}\text { Матеріал і висота ярусів } \\
\text { насадки, м: } \\
\text { перший ярус - динас } \\
\text { другий ярус - ШВ-42 } \\
\text { третій ярус - ШВ-37 } \\
\text { четвертий ярус - ШВ-37 }\end{array}$ & $\begin{array}{c}12,6 \\
9,3 \\
6,8 \\
8,4\end{array}$ \\
\hline Діаметр насадки, м & 6,40 \\
\hline Поверхня нагріву насадки, ${ }^{2}$ & 57248 \\
\hline Об'єм насадки, м ${ }^{3}$ & 1193 \\
\hline $\begin{array}{l}\text { Площа перерізу насадки для } \\
\text { проходу теплоносіїв, } \text { м }^{2}\end{array}$ & 11,57 \\
\hline $\begin{array}{l}\text { Загальна площа перерізу } \\
\text { насадки, м² }\end{array}$ & 32,14 \\
\hline
\end{tabular}
технологічного кисню в повітронагрівачах доменних печей. 3 використанням запропонованої методики досліджено роботу блоку повітронагрівачів доменної печі, який складається 3 трьох теплообмінників, обладнаних насадкою 3 діаметром каналів 30 мм. Характеристику насадки наведено в табл. 1.

Таблиця 1. Характеристика насадки повітронагрівачів доменної печі 
В якості базового варіанту прийнята робота блоку повітронагрівачів при їх опаленні змішаним газом 3 теплотою згоряння 4,478 МДж/ $\mathrm{m}^{3}$, який складається з 97,33 \% доменного газу ка-

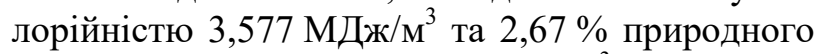

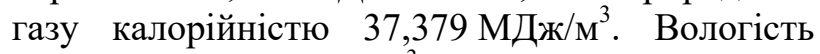

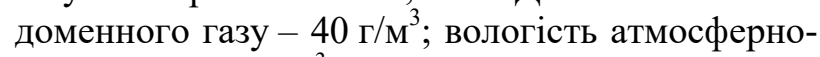
го повітря -10 г $/ \mathrm{M}^{3}$; об'ємний відсоток кисню в атмосферному повітрі - $21 \%$. Коефіцієнт витрати повітря при спалюванні палива - 1,05. Температури палива та атмосферного повітря відповідно $-30{ }^{\circ} \mathrm{C}$ та $10^{\circ} \mathrm{C}$. Витрата дуття $-50 \mathrm{~m}^{3} / \mathrm{c}$ (180 тис. $\mathrm{M}^{3} /$ год), тривалість періоду нагрівання насадки - 2,5 год, тривалість періоду нагрівання дуття - 1,25 год.

Як показали розрахунки, при прийнятих вихідних даних витрата змішаного газу на опа-

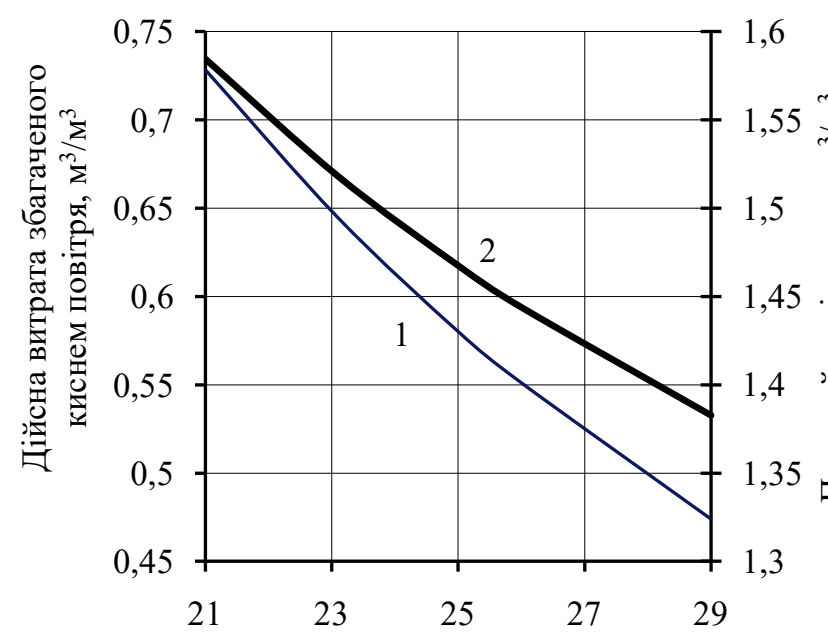

Об'ємний відсоток кисню в повітрі горіння

Рис. 1. Залежність дійсної витрати збагаченого повітря (1) і питомого виходу диму (2) від вмісту кисню в повітрі горіння

Рис. 1 демонструє вплив концентрації кисню в повітрі горіння на дійсну витрату збагаченого повітря і питомий вихід димових газів. Як видно з рисунка, при збільшенні частки кисню в повітрі дійсна витрата збагаченого повітря знижується за рахунок зниження кількості азоту, який надходить 3 повітрям, що призводить до зменшення питомого виходу продуктів згоряння. Так як калориметрична температура горіння палива, а отже і температура під куполом повітронагрівача обернено пропорційно залежать від питомого виходу продуктів згоряння, то при збагаченні повітря киснем обидві температура збільшуються.

На рис. 2 показано зміну температури під куполом повітронагрівача в залежності від вмісту технологічного кисню в повітрі горіння. 3 лення одного повітронагрівача складає 47279 $\mathrm{m}^{3} /$ год, в тому числі $46018 \mathrm{~m}^{3} /$ год доменного газу та $1261 \mathrm{~m}^{3} /$ год природного газу. Калориметрична температура горіння палива $-1452{ }^{\circ} \mathrm{C}$, температура під куполом повітронагрівача $-1350{ }^{\circ} \mathrm{C}$. Температури нагріву дуття: на початку періоду $1330{ }^{\circ} \mathrm{C}$; наприкінці періоду $-1223{ }^{\circ} \mathrm{C}$. Температура диму на виході з повітронагрівача: на початку періоду нагрівання насадки $-134{ }^{\circ} \mathrm{C}$; наприкінці періоду $-398{ }^{\circ} \mathrm{C}$. Витрата димових газів через насадку $-87504 \mathrm{~m}^{3} /$ год.

Для умов роботи повітронагрівачів на доменному газі та використанні збагаченого киснем повітря виконано розрахунки горіння доменного газу, калориметричної температури та температури під куполом повітронагрівача, результати яких наведено на рис. 1 i 2.

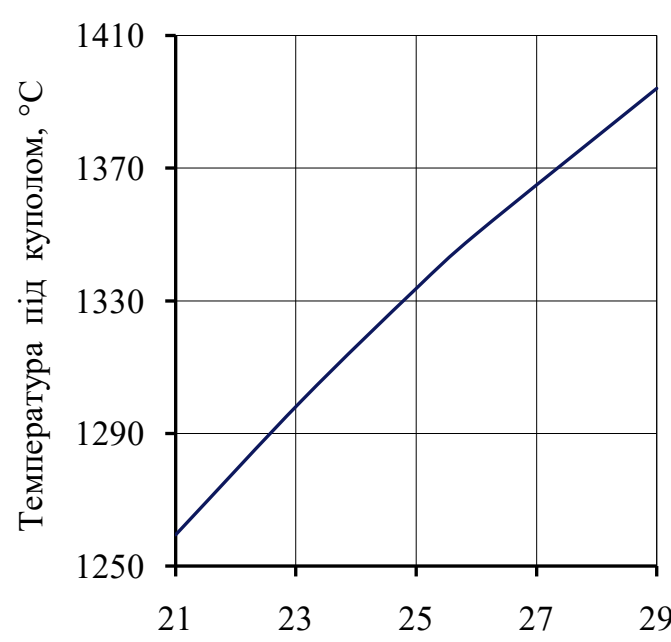

Об'ємний відсоток кисню в повітрі горіння

Рис. 2. Залежність температури під куполом від вмісту кисню в повітрі горіння

рисунків 1 і 2 видно, що збільшення концентрації кисню з 21 до $29 \%$ забезпечує зростання температури під куполом з 1260 до $1394{ }^{\circ} \mathrm{C}$ та призводить до зниження питомого виходу диму з 1,58 до $1,38 \mathrm{~m}^{3} / \mathrm{m}^{3}$.

Як показали розрахунки, для забезпечення температури під куполом повітронагрівача $1350{ }^{\circ} \mathrm{C}$ та однакових параметрів теплообміну в насадці при базовому варіанті роботи та після заміни палива на доменний газ, об’ємний відсоток кисню в повітрі горіння повинен складати $26 \%$. При цьому витрати доменного газу і технологічного кисню на один повітронагрівач складають $60589 \mathrm{~m}^{3} /$ год та $2230 \mathrm{~m}^{3} /$ год відповідно.

Результати розрахунку економічної ефективності розглянутих варіантів роботи блоку повітронагрівачів наведено в табл. 2. Під час 
розрахунків прийнято, що вартість доменного газу - 2300 грн/тис. ${ }^{3}$, природного газу -
520 грн/тис. м $^{3}$ і технологічного кисню 7555 грн/тис. $\mathrm{M}^{3}$.

Таблиця 2. Показники роботи блоку повітронагрівачів

\begin{tabular}{|l|c|c|}
\hline \multicolumn{1}{|c|}{ Показник } & $\begin{array}{c}\text { Базовий варіант } \\
\text { (використання для спалювання } \\
\text { палива атмосферного повітря) }\end{array}$ & $\begin{array}{c}\text { При збагаченні } \\
\text { повітря горіння } \\
\text { киснем }\end{array}$ \\
\hline Паливо & змішаний газ & доменний газ \\
\hline Об’ємний відсоток кисню в повітрі горіння,\% & 21 & 26 \\
\hline $\begin{array}{l}\text { Витрати на блок повітронагрівачів, } \text { м }^{3} / \text { год: } \\
\text { - доменного газу } \\
\text { - природного газу } \\
\text { - технологічного кисню }\end{array}$ & 92036 & 121178 \\
\hline Витрати на паливо та технологічний кисень, грн/год & 2522 & 4460 \\
\hline $\begin{array}{l}\text { Питомі витрати на паливо та технологічний } \\
\text { кисень, грн/тис. м }{ }^{3} \text { дуття }\end{array}$ & 66912,43 & 73270,56 \\
\hline
\end{tabular}

Аналіз отриманих результатів показав, що в базовому варіанті при опаленні повітронагрівачів змішаним газом витрата доменного газу на блок повітронагрівачів - 92036 м $^{3} /$ год; витрата природного газу - $2522 \mathrm{~m}^{3} /$ год. При витраті дуття 180 тис. $\mathrm{M}^{3} /$ год та прийнятих цінах на енергоносії питомі витрати на опалення блоку повітронагрівачів складають 371,74 грн /тис. м ${ }^{3}$ дуття.

Збагачення повітря горіння технологічним киснем дозволяє відмовитися від використання природного газу для опалення повітронагрівачів. При цьому температура під куполом повітронагрівача $1350{ }^{\circ} \mathrm{C}$ забезпечується при вмісті кисню в повітрі горіння $26 \%$, а витрати доменного газу і технологічного кисню на блок повітронагрівачів складають $121178 \mathrm{~m}^{3} /$ год і $4460 \mathrm{~m}^{3} /$ год відповідно. При витраті дуття 180 тис. $\mathrm{M}^{3} /$ год реалізація цього варіанта роботи, в порівнянні з базовим варіантом, призводить до зростання питомих витрат на опалення блоку повітронагрівачів 3 354,77 до 407,06 грн/тис. м ${ }^{3}$ дуття (що становить 35,32 грн/тис. м ${ }^{3}$ дуття або $9,5 \%$ ) за рахунок використання 39,07 млн. ${ }^{3} /$ рік технологічного кисню і збільшення витрати доменного газу на 255,28 млн. м $^{3} /$ рік.

Максимальна ціна технологічного кисню, що забезпечує беззбитковість його використання, при прийнятих цінах на природний та доменний гази, визначена за формулою (10), повинна складати 874,41 грн/тис. м $^{3}$.

Збільшення витрати доменного газу може бути покрито за рахунок скорочення його споживання іншими агрегатами металургійного комбінату. У той же час значні витрати технологічного кисню роблять впровадження цього заходу майже неможливими без введення в експлуатацію додаткових виробничих потужностей 3 його виробництва або без виведення з експлуатації його постійних споживачів. Сказане вище дає підстави вважати, що при прийнятих цінах застосування технологічного кисню для збагачення повітря горіння для підігрівання доменного дуття є економічно недоцільним.

Слід також зазначити, що ціни доменного газу і технологічного кисню не є постійними, а регулярно переглядаються підприємствами i можуть істотно відрізнятися на різних металургійних комбінатах. Ціна доменного газу визначається собівартістю його виробництва, очищення й транспортування, а однією 3 істотних статей витрат у собівартості технологічного кисню є витрата електроенергії на його виробництво, яка в залежності від технології, що застосовується, може змінюватися в 3,5 рази (з 330 до 1150 кВт·год/тис.м ${ }^{3}$ кисню) [2]. Тому остаточний висновок про економічну доцільність переведення повітронагрівачів на опалення доменним газом 3 використанням збагаченого технологічним киснем повітря горіння можна робити тільки з урахуванням особливостей конкретного підприємства та його цінової політики на вторинні енергоресурси і технологічний кисень.

Дослідження ефективності використання технологічного кисню в нагрівальних печах та котлах ТЕЦ. Використання кисню для економії природного газу розглянуто на прикладі роботи парового котла i методичної печі, яка обслуговує дрібносортний стан. Прийнято, що зазначені теплові агрегати опалюються природ-

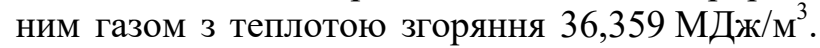
Теоретична витрата атмосферного повітря на спалювання палива $-9,651 \mathrm{~m}^{3} / \mathrm{m}^{3}$.

Методична піч 3 монолітним подом шириною 12,5 м та довжиною 25 м працює по трьохзонному температурному режиму. Температура димових газів на виході 3 печі $-900{ }^{\circ} \mathrm{C}$. Атмосферне повітря, що подається на спалювання палива, підігрівається в металевому трубчастому 
рекуператорі до $210{ }^{\circ} \mathrm{C}$.

ТЕЦ обладнано паровими котлами ПК-14$2 \mathrm{M}$, на виході 3 яких температура димових газів становить $150{ }^{\circ} \mathrm{C}$. Підігрів повітря, що подається на спалювання палива в котлах, не передбачений.

Зміну коефіцієнтів використання теплоти палива, в залежності від вмісту кисню в повітрі горіння для умов роботи котла та методичної печі, наведено в табл. 3. Порівняння результатів розрахунків за формулою (13) показує, що ефек- тивність використання збагаченого киснем повітря в методичній печі значно вище, ніж в котлі ТЕЦ. Як видно з таблиці, при збагаченні повітря до вмісту кисню $31 \%$ коефіцієнт використання теплоти палива в котлі збільшується з 0,941 до 0,957 , а економія палива досягає $1,7 \%$, в той час, як для методичної печі збільшення коефіцієнту використання теплоти палива 30,645 до 0,73 забезпечує економію палива $11,6 \%$.

Таблиця 3. Значення коефіцієнтів використання теплоти палива та економії палива при збагаченні повітря горіння киснем

\begin{tabular}{|c|c|c|c|c|}
\hline \multirow{2}{*}{$\begin{array}{c}\text { Об'ємний відсоток кисню } \\
\text { в повітрі горіння }\end{array}$} & \multicolumn{2}{|c|}{ Коефіцієнти використання теплоти палива } & \multicolumn{2}{|c|}{ Економія палива, \% } \\
\cline { 2 - 5 } & котел & методична піч & котел & методична піч \\
\hline 21 & 0,941 & 0,645 & - & - \\
\hline 23 & 0,946 & 0,668 & 0,5 & 3,4 \\
\hline 25 & 0,949 & 0,687 & 0,8 & 6,1 \\
\hline 27 & 0,952 & 0,704 & 1,2 & 8,4 \\
\hline 29 & 0,954 & 0,718 & 1,4 & 10,2 \\
\hline 31 & 0,957 & 0,730 & 1,7 & 11,6 \\
\hline
\end{tabular}

Розрахунки показують, що при збагаченні повітря горіння до вмісту кисню $31 \%$ витрата технологічного кисню для економії $1 \mathrm{~m}^{3}$ природного газу для методичної печі складає $6,28 \mathrm{~m}^{3} / \mathrm{m}^{3}$, а для котла $-48,67 \mathrm{~m}^{3} / \mathrm{m}^{3}$, що в 7,8 разів більше. При ціні природного газу 7555 грн/тис.м ${ }^{3}$ максимальна ціна технологічного кисню, яка забезпечує беззбитковість його використання в методичній печі повинна складати 1203,03 грн/тис.м ${ }^{3}$, а в паровому котлі155,23 грн/тис.м ${ }^{3}$.

Висновки. Одним 3 перспективних напрямів підвищення енергоефективності теплотехнічних агрегатів $\epsilon$ використання технологічного кисню при спалюванні палива. В умовах українських металургійних підприємств використання кисню більш доцільно для збагачення повітря, що подається на спалювання палива, оскільки не потребує значної реконструкції системи опалення агрегатів, повної заміни пальникових пристроїв та системи утилізації теплоти димових газів, що відходять. Теплотехнічні агрегати можуть служити ефективними буферними споживачами надлишкового технологічного кисню, який залишився невикористаним у результаті тимчасової зупинки або зниження продуктивності його постійних споживачів, забезпечуючи істотну економію палива.

Запропоновано методику визначення ефективності використання технологічного кисню при спалюванні палива в теплотехнічних агрегатах металургії.
Досліджено теплову роботу блоку повітронагрівачів доменної печі при їх опаленні природно-доменною сумішшю та доменним газом. Виконано порівняння показників роботи повітронагрівачів при спалюванні палива 3 атмосферним та збагаченим киснем повітрям. Аналіз отриманих результатів показав, що використання технологічного кисню для збагачення повітря горіння забезпечує переведення повітронагрівачів на опалення доменним газом і отримання заданої калориметричної температури горіння палива при вмісті кисню у повітрі горіння $26 \%$. При цьому підвищення витрати доменного газу складає $32 \%$ (в порівнянні з роботою повітронагрівачів на природно-доменній суміші). 3 урахуванням додаткових витрат на паливо і технологічний кисень питомі витрати на опалення блоку повітронагрівачів збільшуються на 20,9 \% (або 73,97 грн/тис.м ${ }^{3}$ дуття) не зважаючи на виключення зі складу палива природного газу.

Досліджено зміну показників енергоефективності методичної печі прокатного цеху та парового котла ТЕЦ при їх опаленні природним газом та використанні технологічного кисню для збагачення повітря горіння. Визначено, що ефективність використання кисню в методичних печах $\epsilon$ значно вищою, ніж в котлах. Так, при підвищенні вмісту кисню в повітрі горіння до $31 \%$ економія палива в методичній печі складає $11,6 \%$, а витрата технологічного кисню для економії $1 \mathrm{~m}^{3}$ газу $6,28 \mathrm{~m}^{3} / \mathrm{m}^{3}$, в той час як в котлі ці показники відповідно складають $1,7 \%$ та $48,67 \mathrm{~m}^{3} / \mathrm{m}^{3}$. 


\section{Бібліографічний список}

1. Результаты деятельности ГМК Украины в декабре и за 12 месяцев 2018 года. Аналітичні данні ОП «Укрметалургпром». URL: https://www.ukrmetprom.org/rezultaty-deyatelnostigmk-ukrainy-13/

2. Карп И. Н. Зайвый А. Н., Марцевой Е. П., Пьяных К. Е. Использование кислорода и обогащенного кислородом воздуха в нагревательных печах, колодцах, стендах разогрева сталеразливочных ковшей. Энерготехнологии и ресурсосбережение. 2012. № 3. С. 18-29.

3. R. J. Reed. North American Combustion Handbook. Cleveland, Oh. : North American Mfg. Co., Vol. 2. of the 3rd Edition, 1997. - 457 p.

4. Dilute Oxygen Combustion - Phase 1 Report. Report DOE/ID/13331-T1 (DE98052058)/ U.S. Department of Energy. Washington DC. October, 1997. P. 62-72. URL: https://webapp1. dlib.indiana.edu/virtual_disk_library/index.cgi/ 4297581/FID1887/m98052058.pdf.

5. Oxy-fuel combustion in a rotary hearth heating furnace. URL: http://www.lindemetallurgy. com/pdf/1804_Oxyfuel_rotary_furnace_final.pdf

6. Installation of a 145-MMBtu/hour oxyfuel firing system on the No. 2 reheat furnace at Arcelor Mittal's 84-Inch Hot Strip Mill / E. Black, et al. Iron\&Steel Technol. 2010. Vol. 7, No. 5. P. 278283.

7. $25 \%$ Increased Reheating Throughput and $50 \%$ Reduced Fuel Consumption by Flameless Oxyfuel at ArcelorMittal Shelby - Tubular Products, Ohio / M. Lantz, et. al. Iron \& Steel Technol. 2009. Vol. 6, No 9. P. 29-36.

8. Сорока Б. С. Системы сжигания и теплоутилизационные устройства технологических печей: Современное состояние и мировые тенденции. Энерготехнологии и ресурсосбережение. 2012. № 2. С. 54-68.

9. Кабишов С. М., Трусова И. А., Ратников П. Э., Менделеев Д. В. Интенсификация тепловых процессов в высокотемпературных установках на примере нагревательных печей ОАО «БМЗ» путем обогащения воздуха воздушной смеси кислородом. Литье и металлургия. 2012. № 3(67). C. 218-221.

10. Кабишов С. М. и др. Экономические аспекты обогащения воздушного дутья кислородом в нагревательных и термических печах. Металлургия: республиканский межведомственный сборник научных трудов. Минск : БНТУ, 2014. Вып. 35. С. 8-16.

11. Металлургические печи: Теория и расчеты. В 2 т. / под общ. ред. В. И. Тимошполь- ского, В. И. Губинского. Минск: Белорус. наука, 2007. T. 2. 832 c.

12. Расчет нагревательных и термических печей : справочник / под ред. В. М. Тымчака, В. Л. Гусовского. М. : Металлургия, 1983. 480 с.

13. Металлургические печи: Теория и расчеты. В 2 т. / под общ. ред. В. И. Тимошпольского, В. И. Губинского. Минск: Белорус. наука, 2007. Т. $1.596 \mathrm{c}$.

14. Ревун М. П., Потапов Б. Б. , Ольшанский В. М., Бородулин А. В. Высокотемпературные теплотехнические процессы и установки в металлургии. Запорожье : ЗГИА, 2002. 443 с.

\section{References}

1. Rezultaty deiatelnosti GMK Ukrainy v dekabre i za 12 mesiatcev 2018 goda. (2018). Analitychni danni OP "Ukrmetalurhprom". URL: https://www.ukrmetprom.org/rezultaty-deyatelnostigmk-ukrainy-13/

2. Karp, I. N. Zaivyi, A. N., Martcevoi, E. P., Pianykh, K. E. (2012). Ispolzovanie kisloroda i obogashchennogo kislorodom vozdukha $\mathrm{v}$ nagrevatelnykh pechakh, kolodtcakh, stendakh razogreva stalerazlivochnykh kovshei. Energotekhnologii $i$ resursosberezhenie, (3), 18-29.

3. R. J. Reed. (1997). North American Combustion Handbook (Vol. 2). Cleveland, Oh.: North American Mfg. Co.

4. Dilute Oxygen Combustion- Phase 1 Report. (1997). Report DOE/ID/13331-T1 (DE98052058)/ U.S. Department of Energy. Washington DC. Retrieved from https://webapp1.dlib.indiana.edu/virtual_disk_librar y/index.cgi/4297581/FID1887/m98052058.pdf.

5. Oxy-fuel combustion in a rotary hearth heating furnace. Retrieved from http://www. lindemetallurgy.com/pdf/1804_Oxyfuel_rotary_ furnace_final.pdf

6. Black, E. and Erfurth, F. and Kitko, G. and Hernandez, M. and Kelly, J. and Rosen, L. and Tian, K. (2010). Installation of a 145-MMBtu/hour oxyfuel firing system on the No. 2 reheat furnace at Arcelor Mittal's 84-Inch Hot Strip Mill. Iron\&Steel Technol. 7(5), 278-283.

7. Lantz, M., Hassenzahl, D., Lugnet, A., Moroz, G. \& Carlsson, A. (2009). $25 \%$ Increased Reheating Throughput and $50 \%$ Reduced Fuel Consumption by Flameless Oxyfuel at ArcelorMittal Shelby - Tubular Products, Ohio. Iron \& Steel Technol. 6(9), 29-36.

8. Soroka B. S. (2012). Sistemy szhiganiia i teploutilizatcionnye ustroistva tekhnologicheskikh pechei: Sovremennoe sostoianie i mirovye tendent- 
cii. Energotekhnologii i resursosberezhenie. (2), 5468.

9. Kabishov, S. M., Trusova, I. A., Ratnikov, P. E., \& Mendeleev, D. V. (2012) Intensifikatciia teplovykh protcessov $\mathrm{v}$ vysokotemperaturnykh ustanovkakh na primere nagrevatelnykh pechei OAO "BMZ" putem obogashcheniia vozdukha vozdushnoi smesi kislorodom. Lite i metallurgiia. (3(67)), 218-221.

10. Kabishov, S.M., Trusova, I.A., Ratnikov, P. E., Mendelev, D.V., \& Rumyanceva G. A. (2014). Ekonomicheskie aspekty obogashcheniia vozdushnogo dutia kislorodom v nagrevatelnykh i termicheskikh pechakh. Metallurgiia: respublikanskii mezhvedomstvennyi sbornik nauchnykh trudov (Vol. 35, pp. 8-16). Minsk : BNTU.

11. Timoshpolskii, V. I., \& Gubinskii, V. I. (Eds.).(2007). Metallurgicheskie pechi: Teorija $i$ raschety. (Vol. 2). Minsk: Belorus. nauka.

12. Tymchak, V. M., \& Gusovskii, V. L. (Eds.). (1983). Raschet nagrevatelnyh i termicheskih pechej: spravochnik. Moskva: Metallurgija.

13. Timoshpolskii, V. I., \& Gubinskii, V. I. (Eds.).(2007). Metallurgicheskie pechi: Teorija $i$ raschety. (Vol. 1). Minsk: Belorus. nauka.

14. Revun, M. P., Potapov, B. B. , Olshanskii, V. M., \& Borodulin, A. V. (2002). Vysokotemperaturnye teplotekhnicheskie protcessy $i$ ustanovki $v$ metallurgii. Zaporozhe: ZGIA.

Цель - разработка методики определения эффективности использования технологического кислорода для обогащения воздуха горения при отоплении теплотехнических агрегатов в металлургии.

Методика. При выполнении исследований использованы: математическая модель воздухонагревателя, позволяющая при заданных конструктивных параметрах насадки и расходе дутья определять расход топлива, воздуха горения и дымовых газов, изменение температуры дымовых газов и дутья по высоте насадки; методика расчета горения топлива и определения калориметрической температуры горения; методика расчета коэффициента использования теплоты топлива.

Результаты. Исследование тепловой работы воздухонагревателей доменной печи позволило определить, что использование технологического кислорода для обогащения воздуха горения обеспечивает работу воздухонагревателей на доменном газе и получение заданной температуры дутья при содержании кислорода в воздухе горения $26 \%$, но требует увеличения расхода доменного газа на
$32 \%$. При этом удельные затраты на отопление блока воздухонагревателей увеличиваются на 20,9\%, что делает внедрение этого мероприятия экономически нечелесообразным. Исследование изменения показателей энергоэффективности методической печи и парового котла при их отоплении природным газом и использовании для сжигания топлива атмосферного или обогащенного кислородом воздуха позволило установить, что эффективность использования кислорода в методической печи значительно выше, чем в котле. При повышении содержания кислорода в воздухе горение до $31 \%$ экономия топлива в методической печи составляет 11,6\%, а удельный расход технологического кислорода$6,28 \mathrm{~m}^{3} / \mathrm{m}^{3}$ сэкономленного природного газа, в то время как в котле эти показатели соответственно составляют $1,7 \%$ и $48,67 \mathrm{~m}^{3} / \mathrm{m}^{3}$.

Научная новизна. С использованием расчетных методов и математического моделирования тепловой работы доменных воздухонагревателей обосновано, что использование технологического кислорода для обогащения воздуха горения обеспечивает получение заданной температуры дутья и экономию природного газа, однако требует существенного увеличения расхода доменного газа. Получена аналитическая зависимость, обосновывающяая максимальную стоимость технологического кислорода, при которой его применение является экономически иелесообразным при нагреве доменного дутья. Для нагревательных печей и паровых котлов, отапливаемых природным газом и использующих для сжигания топлива атмосферный воздух, обогащенный технологическим кислородом, установлены аналитические зависимости, позволяющие определить: расход технологического кислорода для экономии $1 м^{3}$ топлива; максимальную стоимость технологического кислорода, при которой его применение не приводит к росту суммарных затрат на топливо и технологический кислород.

Практическая значимость. Предложенные методики определения эффективности использования технологического кислорода для обогащения воздуха горения при сжигании топлива могут применяться в системах энергетического менеджмента металлургического комбината для управления тепловым балансом предприятия и выбора теплотехнических агрегатов, в которых использование временных излишков технологического кислорода обеспечивает наибольшую экономию топлива и является экономически целесообразным. 
Ключевые слова: воздухонагреватель, печь, котел, топливо, природный газ, доменный газ, технологический кислород.

The purpose of the paper is to develop a method for determining the efficiency of the use of process oxygen for the enrichment of combustion air in the metallurgical heating equipment.

Methods. In the course of the research, the following was used: mathematical model of the hot-blast stove, which allows to determine the consumptions of fuel, combustion air, and flue gases, the changes of flue gas and air blast temperatures along the checker chamber at given design parameters and air blast consumption; the method of calculation of fuel combustion processes and the calorimetric temperature of fuel.

Results. The study of the thermal operation of hot-blast stoves allowed to determine that the use of process oxygen for the enrichment of combustion air provides the operation of hot-blast stoves and the preset blasting temperature when the oxygen content in the combustion air is $26 \%$, but requires an increase of the blast-furnace gas consumption by $32 \%$. For hot-blast stoves, the specific cost of heating increases by 20.9\%, which makes the implementation of this measure economically impractical. The study of changes in the energy efficiency of the continuous furnace and the steam boiler, which use atmospheric or oxygenenriched air for combustion process, allowed to determine that the efficiency of use of oxygen in the continuous furnace is much higher than in the boiler. When the oxygen content in the combustion air increases up to $31 \%$, the fuel saving for the continuous furnace is $11.6 \%$ and the specific consumption of process oxygen is $6.28 \mathrm{~m}^{3}$ per $1 \mathrm{~m}^{3}$ of saved natural gas. At the same time, these figures for boilers respectively are $1.7 \%$ and $48,67 \mathrm{~m}^{3} / \mathrm{m}^{3}$.

Scientific novelty. Using mathematical modelling of hot-blast stoves operation, it was proved that the use of process oxygen for the enrichment of combustion air provides the predetermined air blast temperature and natural gas saving, but requires a significant increase of blast furnace gas consumption. An analytical dependence that substantiates the maximum cost of process oxygen for its break-even use in the hot-blast stoves was established. For the furnace and steam boiler, both of which use the atmospheric air enriched with process oxygen for combustion process, the following analytical dependencies were determined: the consumption of process oxygen for saving $1 \mathrm{~m}^{3}$ of fuel; the maximum cost of process oxygen, in which its use does not lead to an increase in the total cost of fuel and process oxygen.

Practical significance. The developed method for determining the efficiency of the use of process oxygen for the enrichment of combustion air can be used in the energy management systems of metallurgical plants to control the thermal balance of the plant and chose the units, in which the use of temporary excess of process oxygen allows to avoid its losses and provide the greatest savings.

Key words: hot-blast stove, furnace, boiler, fuel, natural gas, blast furnace gas, process oxygen.

Рукопис надійшов 15.07.2019 